American Journal of Environmental Sciences 4 (3): 223-228, 2008

ISSN 1553-345X

(C) 2005 Science Publications

\title{
Valorization of Drinking Water Treatment Sludges as Raw Materials to Produce Concrete and Mortar
}

\author{
${ }^{1}$ R.M. Ramirez Zamora, ${ }^{1}$ O. Ceron Alfaro, ${ }^{1}$ N. Cabirol, ${ }^{1}$ F. Espejel Ayala and ${ }^{2}$ A. Duran Moreno \\ ${ }^{1}$ Institute of Engineering, National Autonomous University of Mexico, \\ Ciudad Universitaria, DF 04510, México \\ ${ }^{2}$ Department of Chemistry Engineering, Faculty of Chemistry, \\ National Autonomous University of Mexico, Ciudad Universitaria, DF 04510, México
}

\begin{abstract}
The purpose of this work was to assess the technical feasibility to valorize sludges, generated and stored at the Los Berros drinking water facility (PPLB), as raw material to produce building products (mortar and concrete) for the construction industry. The experimental study was divided into three stages: 1) sampling and characterization of PPLB sludges to determine their potential as raw material (sand substitute and supplementary cementing materials) to produce mortar and concrete; 2) production and characterization of specimens, using sludge in different weight ratios of mixtures with cement, lime, commercial mortar and plaster to prepare mortars and concretes and 3) comparison of compressive strength and drying contraction values between each specimen and the Mexican criteria to build mortars and concretes. The characterization results of the PPLB sludges showed that these residues could be used as a sand substitute in mortar and concrete formulations, since they were mainly comprised of this material $(46.83 \%)$. The specimens prepared with a) the binary formulations, sludge-cement and sludge-mortar (90$10 \%)$ and b) the ternary formulation, sludge-lime-cement (90-5-5\%), gave the best results (ranging from 130 to $150 \mathrm{~kg} \mathrm{~cm}^{-2}$ ) of the compressive strength test. The compressive strength values of these formulations were higher than those of equivalent mortar (types I, II and III) and cement mixtures $\left(125 \mathrm{~kg} \mathrm{~cm}^{-2}\right.$ ) prepared according to the Mexican complementary technical criteria to design and build masonry. These cementing properties exhibited by the PPLB sludges might be associated to their high content of aluminum and silicon oxides, 31.98 and $33.23 \%$, respectively. Thus, calcium silicate (the main carrier strength in hardened cement) can be produced from lime hydration of cement with the active silica present in the sludge. Considering all these results, the PPLB sludges present a high feasibility for being valorized as raw materials (supplementary cementing material and sand substitute) to produce building products for the construction industry.
\end{abstract}

Key words: Concrete, drinking water sludge, mortar, valorization

\section{INTRODUCTION}

In Mexico, $2.8 \times 109 \mathrm{~m}^{3}$ year $^{-1}$ (average flow rate) of raw water are treated in approximately 307 drinking water facilities ${ }^{[1]}$. From the total flow rate, $22.5 \%$ $\left(6.3 \times 108 \mathrm{~m}^{3}\right.$ year $\left.^{-1}\right)$ is processed in Los Berros drinking water facility (PPLB), located at the north of Mexico City. PPLB starts in 1985 and the sludges generated have been traditionally stored in protected sites located in the PPLB. Nevertheless, these sites have already reached their maximum capacity making necessary to find a solution to avoid their final disposal into the environment ${ }^{[1]}$. One of the most feasible alternatives to solve this situation is their valorization as raw materials in the elaboration of different products.

Drinking water sludges have traditionally been classified as wastes. However, they present chemical compounds, such as calcium, silicon, etc., similar to those reported in literature as raw materials used to elaborate ceramic products ${ }^{[2-9]}$, for the preparation of adsorbents and catalysts ${ }^{[10]}$ and as soil substitute for land application and elaboration of fire-breaks in woods ${ }^{[11-15]}$. Moreover, due to the residual content of aluminum, drinking water sludges can be used to clarify wastewaters. Also, these residues have shown similar physicochemical characteristics to the raw materials used to elaborate sun-dried bricks, despite that this use

Corresponding Author: R. M. Ramirez Zamora, Institute of Engineering, National Autonomous University of Mexico, Cd. Universitaria, 04510 DF, Mexico Tel: +525556233600 (8657 8668) 
has not been reported in literature. However, considering that this type of brick is widely used in Mexico to build houses and recently the government has authorized the construction of apartments and houses near to the PPLB, the application of sludge as raw material to elaborate mortars and concretes could be the most feasible valorization option to be considered.

Based on this situation, this work was intended to assess the technical feasibility to valorize the sludge, generated and stored at the Los Berros drinking water facility (PPLB), as raw material to produce building products (mortar and concrete) used in the construction industry.

\section{MATERIALS AND METHODS}

The experimental study was divided into three stages: 1) sampling and characterization of PPLB sludges to determine their potential as raw material (sand substitute and supplementary cementing material) to produce mortar and concrete; 2) production and characterization of specimens, using sludge in different ratios of mixtures with cement, lime, commercial mortar and plaster to prepare mortars and concretes and 3 ) comparison between results obtained in compressive strength and drying contraction tests for each specimen and the Mexican criteria to build mortars and concretes.

Sampling and characterization of PPLB sludges: Samples of the PPLB sludge were collected in duplicate in the stored sites at three different points and at three different depths $(1,3$ and $5 \mathrm{~m}$ ) during the rainy season (August 2005). For each sample collected, a same amount of sample (100 g) was weighted and mixed for analysis. The parameters measured were: $\mathrm{pH}$, humidity, texture, aluminum, iron, heavy metals and oxides content. All samples were analyzed according to the Standard Methods for the Examination of Water and Wastewater ${ }^{[16]}$ and the Standard Methods for Water and Effluents Analysis ${ }^{[17]}$. Where analysis was not immediately possible, the samples were preserved to inhibit biodegradation. All the reagents used for the analysis were of analytical grade

Elaboration of specimens with drinking water sludges: Sludge was mixed with cement, lime, plaster and a commercial mortar to elaborate cube specimens of $50 \mathrm{~mm}$ according to the C 109ASTM standardized technique for Compressive Strength of Hydraulic Cement Mortars (Using $50 \mathrm{~mm}$ Cube Specimens).
Table 1 shows the composition of the binary and ternary mixtures prepared with PPLB sludges to elaborate cube specimens.

The technique applied in the elaboration of the cube specimens consisted in weighting and mixing, according to the composition described in Table 1, a given amount of sludge and typical build material (cement, lime, plaster, mortar and sand) to obtain a homogenized mixture. Before preparing specimens, mixtures were tested for fluidity. After that, each homogenized mixture was added to wooden molds to prepare the cube specimens.

The mixture was tamped four times on each side of the mold; this step was repeated three times until the mold was completely filled up. The excess of the mixture was removed from the top of the mold using a spatula. After 24 hours, the specimens were removed from the molds and placed for drying in a closed moist room at constant temperature $\left(20^{\circ} \mathrm{C}\right)$ during 14 and 28 days. Finally, shrinking and compressive strength tests were carried out to the dried specimens. The analytical techniques used to measure each characterization parameter are listed in Table 2.

Table 1: Composition of binary and ternary specimens using PPLB sludges

\begin{tabular}{|c|c|c|c|c|c|c|}
\hline \multirow{2}{*}{$\begin{array}{l}\text { Binary } \\
\text { mixture }\end{array}$} & \multicolumn{6}{|c|}{ Composition $(\%, \mathrm{v} / \mathrm{v})$} \\
\hline & $100-0$ & $90-10$ & $75-25$ & $40-60$ & $25-75$ & $0-100$ \\
\hline Sludge & $\checkmark$ & & & & & \\
\hline Sludge-cement & & $\checkmark$ & $\checkmark$ & $\checkmark$ & $\checkmark$ & $\checkmark$ \\
\hline Sludge-lime & & $\checkmark$ & $\checkmark$ & $\checkmark$ & $\checkmark$ & $\checkmark$ \\
\hline Sludge-plaster & & $\checkmark$ & $\checkmark$ & $\checkmark$ & $\checkmark$ & $\checkmark$ \\
\hline Sludge-mortar & & $\checkmark$ & $\checkmark$ & $\checkmark$ & $\checkmark$ & $\checkmark$ \\
\hline
\end{tabular}

\begin{tabular}{lcccc} 
& Composition $(\%, v / v)$ & & \\
Ternary & $-0 .-5-5$ & $75-12.5-12.5$ & $40-30-30$ & $25-37.5-37.5$ \\
mixture & $90-5$ & $\checkmark$ & $\checkmark$ & $\checkmark$ \\
\hline Sludge-plaster-cement & $\checkmark$ & $\checkmark$ & $\checkmark$ & $\checkmark$ \\
Sludge-plaster-lime & $\checkmark$ & $\checkmark$ & $\checkmark$ & $\checkmark$ \\
Sludge-lime-cement & $\checkmark$ & $\checkmark$ &
\end{tabular}

Table 2: Analytical techniques to determine fluidity, compressive strength and contraction caused for drying

\begin{tabular}{lll}
\hline Technique & ASTM & Specification \\
\hline Fluidity & C 230 & $\begin{array}{l}\text { Flow Table for Use in Tests in } \\
\text { hydraulic Cement }\end{array}$ \\
Compressive strength (RC) C 109 & $\begin{array}{l}\text { Compressive strength of cement } \\
\text { hydraulic mortar (using cubic } \\
\text { specimens of 5.08 cm). }\end{array}$ \\
Shrinking (CxS) & $\begin{array}{l}\text { C 157/C 157M Standard Test } \\
\text { Method for Change of length of } \\
\text { cement hardening hydraulic and } \\
\text { concrete mortar. }\end{array}$ \\
\hline
\end{tabular}

ASTM: American Society for Testing and Materials 
Am. J. Environ. Sci., 2 (2): xx-xx, 2005

Table 3: Average oxides content determined in the drinking water sludge evaluated in this study

\begin{tabular}{llllllllllll}
\hline Oxides content $(\%)$ & $\mathrm{SiO}_{2}$ & $\mathrm{Al}_{2} \mathrm{O}_{3}$ & $\mathrm{Fe}_{2} \mathrm{O}_{3} \mathrm{t}$ & $\mathrm{TiO}_{2}$ & $\mathrm{MnO}$ & $\mathrm{MgO}$ & $\mathrm{CaO}$ & $\mathrm{Na}_{2} \mathrm{O}$ & $\mathrm{K}_{2} \mathrm{O}$ & $\mathrm{P}_{2} \mathrm{O}_{5}$ & $\mathrm{LxC}$ \\
\hline Sludges & 33.23 & 31.98 & 4.94 & 0.48 & 0.32 & 0.63 & 0.64 & 0.41 & 0.43 & 0.4 & 26.1 \\
\hline
\end{tabular}

$\mathrm{LxC}=$ Lost for calcination

\section{RESULTS AND DISCUSSION}

Sampling and characterization of drinking water sludges: Table 3 and 4 show the values of the physicochemical parameters determined in the mixed sample of the PPLB sludges. Table 3 illustrates that the stored PPLB sludges had a high content of silicon and aluminum oxides (19.58\% and $33.01 \%$, respectively). Since $\mathrm{SiO}_{2}$ fraction is an important component of mortar and concrete formulations, due to its role in pozzolanic reactions, the PPLB sludges could be used as sand substitute. Moreover, the PPLB sludges presented high percentages of sand $(46.86 \%$ for stored sludges and $56.16 \%$ for produced sludges) making them suitable for this application.

Finally, heavy metals contents met the limits recommended by the Mexican norm NOM-004SEMARNAT-2002 ${ }^{[18]}$ for biosolids Class C (Table 4).

Elaboration of specimens with drinking water sludges: The second stage considered the elaboration and characterization tests of the specimens prepared using different formulations, mainly binary (Table 5) or ternary (Table 6) mixtures composed of drinking water sludges and raw materials such as cement, lime, plaster and mortar.

From Table 5, specimens elaborated using sludge contents up to $75 \%(\mathrm{w} / \mathrm{w})$, showed higher compressive strength (RC) values (ranging from 43.26 to $146.8 \mathrm{~kg} \mathrm{~cm}^{-2}$ ). Binary specimens elaborated with sludge-mortar (90\%-10\%) had RC values for both 14 and 28 days similar to results obtained from a specimen produced using $100 \%$ mortar. These results showed that drinking water sludges not only presented characteristics for substituting sand in mixtures but also they showed good cementing properties, which improved significantly the mechanical resistance of specimens.

The improvement of the mechanical properties might be associated to the high content of aluminum and silicon oxide (31.98 and $33.23 \%$, respectively). This silicon could be present as calcium silicate, which is the main carrier strength in hardened cement, produced from lime hydration of cement with the active silica presents in the sludge ${ }^{[19]}$. Due to the cementing and/or pozzolanic properties exhibited by the PPLB
Table 4: Average values (dry basis) of physico-chemical parameters determined in the drinking water sludge evaluated in this study

\begin{tabular}{lcc}
\hline Parameter & Biosolids Class C* & Average value (sludge) \\
\hline Sand $(\%)$ & NS & 46.830 \\
Silt $(\%)$ & NS & 32.640 \\
Clay $(\%)$ & NS & 20.200 \\
Humidity $(\%)$ & NS & 86.180 \\
Aluminum $(\mathrm{mg} / \mathrm{kg})$ & NS & 88392 \\
Chromium $(\mathrm{mg} / \mathrm{kg})$ & 3,000 & 2.860 \\
Arsenic $(\mathrm{mg} / \mathrm{kg})$ & 75 & 1.300 \\
Cadmium $(\mathrm{mg} / \mathrm{kg})$ & 85 & 0.170 \\
Mercury $(\mathrm{mg} / \mathrm{kg})$ & 57 & 0.460 \\
Lead $(\mathrm{mg} / \mathrm{kg})$ & 840 & 16.060 \\
\hline
\end{tabular}

(*) Mexican legislation for biosolids: NOM-004-SEMARNAT$2002^{[18]}$. Norma Oficial Mexicana. Protección Ambiental. Publicada en el Diario Oficial el 15 de agosto de 2003. NS: Non specified

sludges, similar to other solid industrial by-products, such as siliceous and aluminous (fly ash, silica fume, slags, etc.), sludges can be classified as Supplementary Cementing Materials (SCM). The pozzolanic properties could be better observed through a comparison of the compressive strength values between the mixtures of sludge and a non pozzolanic material such as lime (Fig. 1) and sludge and pozzolanic material such as cement (Fig. 2). This comparison allows verifying that drinking water sludge (up to $80 \%$ by weight) improved the mechanical resistance of specimens prepared with non-pozzolanic material such as lime. With respect to sludge-cement mixtures, it was observed that as the sludge proportion increased from 25 to $60 \%$, the strength decreased with regard to the value obtained for the specimen prepared with $100 \%$ cement. However, as sludge proportion increased from 75 to $100 \%$, the sludge strength increased significantly.

These cementing properties could improve the potential of sludges to be used as raw material for preparing mortars and cements used in the construction industry. However, it is worth noting that specimens prepared with mixtures of 75 and $90 \%$ of sludge have shown shrinking values between six to eight times higher than those measured in specimens elaborated with $100 \%$ of lime, plaster, mortar and cement. This result was probably due to the high humidity content of sludges. Thus, it was determined that a previous drying process will be necessarily to reduce the humidity levels in the sludges in order to have better drying shrinkage values. 
Am. J. Environ. Sci., 4 (3): 223-228, 2008

Table 5: Characteristics of cube specimens elaborated with binary mixtures using drinking water sludge

\begin{tabular}{|c|c|c|c|c|c|}
\hline \multicolumn{2}{|c|}{ Binary mixture (\% weight) } & \multirow[b]{2}{*}{$\begin{array}{l}\text { Density } \\
\left(\mathrm{g} \mathrm{cm}^{-3}\right)\end{array}$} & \multirow[b]{2}{*}{$\begin{array}{l}\mathrm{RC}(14 \text { days }) \\
\left(\mathrm{kg} \mathrm{cm}^{-2}\right)\end{array}$} & \multirow[b]{2}{*}{$\begin{array}{l}\mathrm{RC}(28 \text { days }) \\
\left(\mathrm{g} \mathrm{cm}^{-2}\right)\end{array}$} & \multirow[b]{2}{*}{ CXS (\%) } \\
\hline Sludge (\%) & Cement $(\%)$ & & & & \\
\hline 100 & 0 & 1.54 & 168.10 & 146.80 & 84.4 \\
\hline 90 & 10 & 1.34 & 103.30 & 132.30 & 84.4 \\
\hline 75 & 25 & 1.27 & 47.50 & 54.70 & 22.1 \\
\hline 40 & 60 & 0.68 & 3.80 & 2.70 & 22.1 \\
\hline 25 & 75 & 0.76 & 1.20 & 0.80 & 5.9 \\
\hline 0 & 100 & 2.03 & 650.00 & 679.60 & 11.1 \\
\hline Sludge $(\%)$ & Lime (\%) & & & & \\
\hline 90 & 10 & 1.46 & 104.20 & 137.12 & 86.5 \\
\hline 75 & 25 & 0.98 & 31.98 & 27.65 & 61.9 \\
\hline 40 & 60 & 0.50 & 1.58 & 1.87 & 16.9 \\
\hline 25 & 75 & 0.62 & 3.17 & 3.4 & 16.9 \\
\hline 0 & 100 & 0.94 & 5.20 & 7.21 & 18.1 \\
\hline Sludge (\%) & Plaster (\%) & & & & \\
\hline 90 & 10 & 1.46 & 96.38 & 88.33 & 79.1 \\
\hline 75 & 25 & 1.52 & 87.40 & 99.90 & 74.6 \\
\hline 40 & 60 & 1.27 & 41.29 & 64.28 & 66.7 \\
\hline 25 & 75 & 1.08 & 14.38 & 23.56 & 57.3 \\
\hline 0 & 100 & 0.76 & 17.60 & 8.84 & 0.0 \\
\hline Sludge (\%) & Mortar (\%) & & & & \\
\hline 90 & 10 & 1.42 & 94.16 & 150.72 & 83.1 \\
\hline 75 & 25 & 1.36 & 72.22 & 96.66 & 80.5 \\
\hline 40 & 60 & 1.12 & 12.48 & 9.52 & 65.0 \\
\hline 25 & 75 & 0.86 & 3.04 & 2.98 & 36.4 \\
\hline 0 & 100 & 1.59 & 100.00 & 171.20 & 0.0 \\
\hline
\end{tabular}

Table 6: Characteristics of cube specimens elaborated with ternary mixtures using drinking water sludge

\begin{tabular}{|c|c|c|c|c|c|c|}
\hline \multicolumn{7}{|c|}{ Ternary mixture ( $\%$ weight $)$} \\
\hline Sludge (\%) & Plaster (\%) & Cement $(\%)$ & $\begin{array}{l}\text { Density } \\
\left(\mathrm{g} \mathrm{cm}^{-3}\right)\end{array}$ & $\begin{array}{l}\mathrm{RC}(14 \text { days }) \\
\left(\mathrm{kg} \mathrm{cm}^{-2}\right)\end{array}$ & $\begin{array}{l}\mathrm{RC}(21 \text { days }) \\
\left(\mathrm{kg} \mathrm{cm}^{-2}\right)\end{array}$ & CXS (\%) \\
\hline 90 & 5.0 & 5.0 & 1.45 & 93.600 & 97.13 & 80.5 \\
\hline 75 & 12.5 & 12.5 & 1.40 & 78.480 & 53.10 & 79.8 \\
\hline 40 & 30.0 & 30.0 & 0.75 & 4.600 & 4.09 & 40.8 \\
\hline 25 & 37.5 & 37.5 & 0.70 & 17.710 & 19.36 & 2.0 \\
\hline Sludge (\%) & Plaster (\%) & Lime (\%) & & & & \\
\hline 90 & 5.0 & 5.0 & 1.40 & 63.490 & N.D. & 84.8 \\
\hline 75 & 12.5 & 12.5 & 1.40 & 60.340 & N.D. & 80.5 \\
\hline 40 & 30.0 & 30.0 & 0.65 & 2.995 & 3.58 & 27.1 \\
\hline 25 & 37.5 & 37.5 & 0.70 & 11.340 & 12.29 & 0.0 \\
\hline Sludge $(\%)$ & Lime $(\%)$ & Cement $(\%)$ & & & & \\
\hline 90 & 5.0 & 5.0 & 1.45 & 98.210 & 134.92 & 84.2 \\
\hline 75 & 12.5 & 12.5 & 1.25 & 53.340 & 43.26 & 79.8 \\
\hline 40 & 30.0 & 30.0 & 0.40 & 0.420 & 0.90 & 9.7 \\
\hline 25 & 37.5 & 37.5 & 0.60 & 4.840 & 4.33 & 0.0 \\
\hline
\end{tabular}

ND: Value not determined; RC: Compressive Strength. CXS: Drying shrinkage

Table 7 and 8 illustrate the compressive strength values obtained for the best specimens prepared with sludges to those formulations recommended in the Mexican complementary technical criteria for equivalent mortar (types I, II and III) and cement mixtures.

The specimens made with binary mixtures of sludge-cement and sludge-mortar (90-10\%) gave compressive strength values of $132.3 \mathrm{~kg} \mathrm{~cm}^{-2}$ and $150.72 \mathrm{~kg} \mathrm{~cm}^{-2}$, respectively.

These values were higher than the recommended ones $\left(125 \mathrm{~kg} \mathrm{~cm}^{-2}\right)$ by the Mexican complementary technical criteria for equivalent building products (mortar type I and filling concretes) using to design and construct masonry structures (Table 7 and 8).

Similar results achieved with binary mixtures, were obtained using ternary mixtures $(90 \%$ sludge $5 \%$ lime$5 \%$ cement). In this case, the RC value after 28 days of drying was $135 \mathrm{~kg} \mathrm{~cm}{ }^{-2}$, which was higher than the value recommended in Table 7 for an equivalent mortar type II $\left(75 \mathrm{~kg} \mathrm{~cm}^{-2}\right)$ and for an equivalent filling concrete $\left(125 \mathrm{~kg} \mathrm{~cm}^{-2}\right)$.

In almost all specimens (binary or ternary mixtures) prepared with sludge as raw material, it was 
Am. J. Environ. Sci., 2 (2): xx-xx, 2005

Table 7: Compressive strength of specimens elaborated with sludge (binary and ternary mixtures) and of equivalent mortars standard specimens

\begin{tabular}{|c|c|c|c|c|c|c|c|}
\hline \multirow{2}{*}{\multicolumn{3}{|c|}{ Cube specimen }} & \multicolumn{5}{|c|}{ Equivalent mortar* } \\
\hline & & & \multicolumn{4}{|c|}{ Composition (Ratio in vol.) } & \multirow[b]{2}{*}{$\mathrm{RC}\left(\mathrm{kg} \mathrm{cm}^{2}\right)$} \\
\hline Composition & Ratio (vol.) & $\mathrm{RC}_{14-28 \mathrm{~d}}\left(\mathrm{~kg} \mathrm{~cm}^{2}\right)$ & Type & Cement & Lime & Sand & \\
\hline $10 \%$ cement $-90 \%$ sludge & $1: 6$ & $103-132$ & I & 1 & $0-0.25$ & $2.25-3$ & 125 \\
\hline $10 \%$ mortar- $90 \%$ sludge & $3: 6$ & $94-151$ & & & & & \\
\hline $\begin{array}{l}25 \% \text { mortar- } 75 \% \text { sludge } \\
5 \% \text { cement- } \\
5 \% \text { lime- }\end{array}$ & $3: 3$ & $72-97$ & & & & & \\
\hline $\begin{array}{l}90 \% \text { sludge } \\
12.5 \% \text { cement- } \\
12.5 \% \text { lime- }\end{array}$ & $1: 0.5: 12$ & $98-135$ & II & 1 & $0.25-0.5$ & $2.25-3$ & 75 \\
\hline $\begin{array}{l}75 \% \text { sludge } \\
5 \% \text { cement- } \\
5 \% \text { plaster- }\end{array}$ & $1: 0.5: 4$ & $43-53$ & & & & & \\
\hline $\begin{array}{l}90 \% \text { sludge } \\
12.5 \% \text { cement- } \\
12.5 \% \text { plaster- }\end{array}$ & 1:0.72:12 & 93-97 & III & 1 & $0.5-1.25$ & $2.25-3$ & 40 \\
\hline $75 \%$ sludge & 1:0.72:4 & $53-78$ & & & & & \\
\hline
\end{tabular}

Mexican complementary technical criteria for the design and construction of masonry

Table 8: Compressive strength of specimens elaborated with sludge (binary and ternary mixtures) and of an equivalent cement standard specimen Equivalent filling concrete *

Sludge mixture $\quad$ Composition (Ratio in volume)

\begin{tabular}{|c|c|c|c|c|c|c|c|}
\hline Composition & Ratio (vol) & $\begin{array}{l}\mathrm{KC}_{14-28 \mathrm{~d}} \\
\left(\mathrm{~kg} \mathrm{~cm}^{2}\right)\end{array}$ & Cement & Lime & Sand & Crushed stone & $\mathrm{RC}\left(\mathrm{kg} \mathrm{cm}^{2}\right)$ \\
\hline $10 \%$ cement $-90 \%$ sludge & $1: 6$ & $103-132$ & 1 & $0-0.1$ & $2.25-3$ & $1-2$ & 125 \\
\hline $10 \%$ mortar- $90 \%$ sludge & $3: 6$ & $94-151$ & & & & & \\
\hline $5 \%$ cement $-5 \%$ lime- $90 \%$ sludge & $1: 0.5: 12$ & $98-135$ & & & & & \\
\hline
\end{tabular}

Mexican complementary technical criteria for the design and construction of masonry

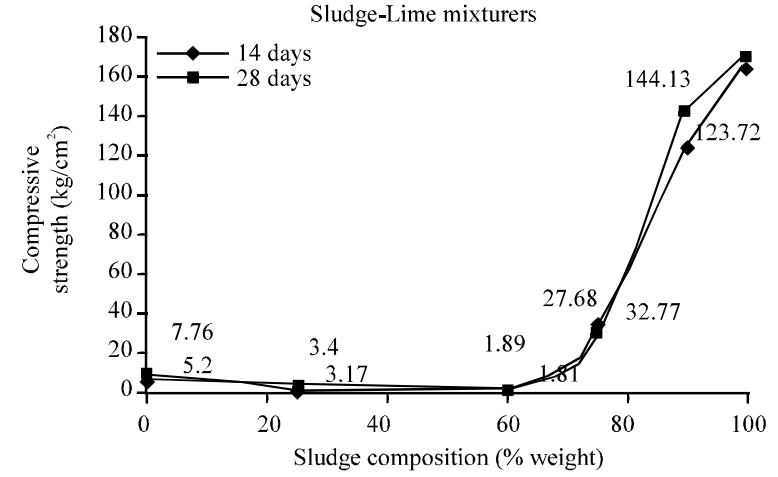

Fig. 1: Compressive strength of cube specimens elaborated with sludge-lime mixtures

obvious an improvement of the mechanical properties for mixtures prepared with high sludge contents (ranging from 75 to $100 \%$ ).Consideringthat the amount of sludge is not a problem since the actual deposits in the PPLB, to meet these high contents of sludge to use them as supplementary cementing material to elaborate building products is feasible. Additionally, this sludge valorization option is technically and economically more viable towards other applications.

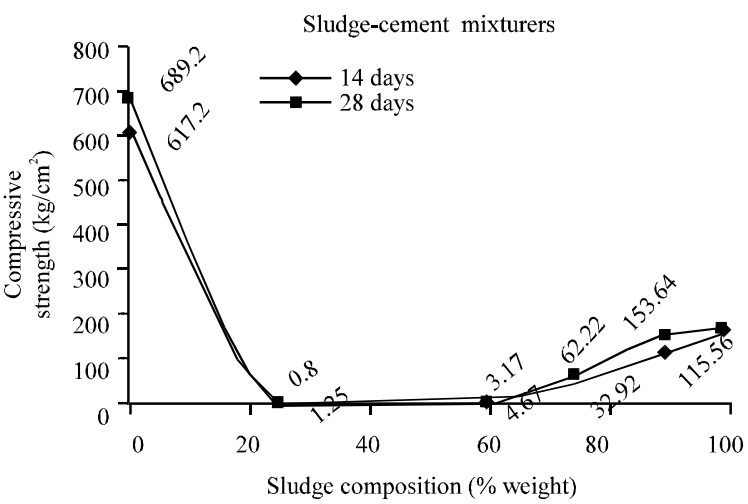

Fig. 2: Compressive strength of cube specimens elaborated with sludge-cement mixtures

\section{CONCLUSIONS}

Based on the results obtained in this study, it can be concluded that it is highly feasible to use PPLB drinking water sludges as supplementary cementing material and sand substitute, as well as to prepare mortars and concretes to be used in the Mexican construction industry. 
The use of sludge in mixtures (up to $75 \%$ in weight) can significantly improve the mechanical resistance of specimens. This phenomenon might be associated to the high sand or silicon oxide content in sludges that increase the calcium silicate content (the main carrier strength in hardened cement), as result of the reaction between the calcium hydroxide produced by lime and cement hydration with the active silica present in the sludge. The best binary (sludge-cement and sludge-mortar 90-10\%) and ternary (90\% sludge $5 \%$ lime $-5 \%$ cement) formulations, prepared to produce cube mortar and concrete specimens, showed compressive strength values (ranging from 130 to $150 \mathrm{~kg} \mathrm{~cm}^{-2}$ ) higher than the proposed values for equivalent standard specimens, according to the Mexican complementary technical criteria for the design and construction of masonry. The high sludge content (90\% in weight) of these mixtures could increase the technical and economical feasibilities of PPLB sludges to be utilized in the construction industry due to the significant volume production that could be assimilated by mortar and cement factories located near to the drinking water facility.

\section{ACKNOWLEGEMENTS}

The authors gratefully acknowledge the Mexican Government National Water Commission (CNA) for the financial support for this research.

\section{REFERENCES}

1. CNA, 2004. Potabilización, desinfección y tratamiento de agua. In: Situación del Subsect agua potable, alcantarillado y saneamiento. Méx. pp: 27.

2. Elías, X., 2000. Valorización de Fangos. Aspectos Ambientales de la Valorización de Cerámica de Fangos. Madrid, Spain.

3. Onaka, T., 2000. Sewage can made Portland cement: A new technology for ultimate reuse of sewage sludge. Wat. Sci. Tech., 41: 93-98.

4. Armenter, J.L., J. Cristiá, J.A. Cusidó, F. Arteaga and L. Cremades, 2002. Innovación en el tratamiento de fangos de una ETAP. Secado por atomización y aprovechamiento en la industria cerámica. Barcelona, Spain.

5. Ferreira, J.M.F. and S.M. Olhero, 2002. Al-rich sludge treatments towards recycling. J. Eur. Ceramic Soc., 22: 2243-2249.

6. Tay, J.H., K.Y. Show, S.Y. Hong, C.Y. Chien and D.J. Lee, 2002. Potential reuse of wastewater sludge for innovative applications in construction industry. Bulletin of College of Engineering, N.T.U., pp: 86.
7. Anderson, M. and R.G. Skerratt, 2003. Variability study of incinerated sewage sludge ash in relation to future use in ceramic brick manufacture. British Ceramic Transactions, 102(3): 109-113.

8. Goldbold, P., K. Lewin, A. Graham and P. Barker, 2003. Reuse of water utility products as secondary commercial materials. WRc. report No. UC 6081.

9. Goncalves, A., A. Esteves and M. Carvalho, 2004. Incorporation of Sludges from a Water Treatment Plant in Cement Mortars. Paper present in The Conference Use of Recycled Materials in Buiding and Structures, November 2004. Barcelona, Spain.

10. Yunusov, K., 1984. Disposal and Utilization of Sludge from Wastewater in Production of Aluminosilicate Catalysts. Plenum Publishing Corporation 009-3092/83/0910-0473. Russia.

11. Gallimore, L.E., N.T. Basta, D.E. Storm, M.E. Payton, R.H. Huhnke and M.D. Smolen, 1999. Water Treatment Residual to Reduce Nutrients in Surface Runoff from Agricultural Land. J. Environ. Qual., 28: 1474-1478.

12. Dayton, E.A. and N.T. Basta, 2001. Characterization of Drinking Water Treatment Residuals for Use as a Soil Substitute. Water. Environ. Res., 73: 52-57.

13. Adler, E., 2002. Gestion des boues d'eau potable à la recherche des bonnes practiques. Synthèse du groupe terres de decantation. (AGHTM) France (personal communication).

14. MENV, 2003. Beneficial Use of Municipal Biosolids in Agriculture. Literature Review and Recommendations Concerning the Impact of Iron and Aluminum Salts on Soil Phosphorus Availability. Ministère de l'Environnement du Québec. Direction des Politiques du secteur agricole. Québec, Canadá.

15. Titshall, L.W. And J.C. Hughes, 2005. Characterization of some South African water treatment residues and implications for land application. Water SA. (31): 3, 299-307. Available on website www.wrc.org.za.

16. APHA-AWWA-WPCF, 1995. Standard methods for the examination of water and wastewater, 18th Edn., USA.

17. Ademoroti CMA., 1996. Standard methods for water and Effluent analysis, Foludex. Press Ltd. Ibadan. pp:182.

18. NOM-004-SEMARNAT-2002. Norma Oficial Mexicana. Protección Ambiental. Publicada en el Diario Oficial el 15 de agosto de 2003.

19. Papadakis, V.G. and S. Tsimas, 2002. Supplementary cementing materials in concrete. Part I: efficiency and design, Cement and Concrete Res., 32: 1525-1532. 